\title{
Common Chicory Performance as Influenced by Iron Concentration in the Nutrient Solution
}

\section{Arthur Bernardes Cecílio Filho, Juan Waldir Mendoza Cortez, Daniel de Sordi \& Miguel Urrestarazu}

To cite this article: Arthur Bernardes Cecílio Filho, Juan Waldir Mendoza Cortez, Daniel de Sordi \& Miguel Urrestarazu (2015) Common Chicory Performance as Influenced by Iron Concentration in the Nutrient Solution, Journal of Plant Nutrition, 38:10, 1489-1494, DOI: 10.1080/01904167.2014.983609

To link to this article: https://doi.org/10.1080/01904167.2014.983609

Accepted author version posted online: 09

Dec 2014.

Published online: $16 \mathrm{Jul} 2015$.

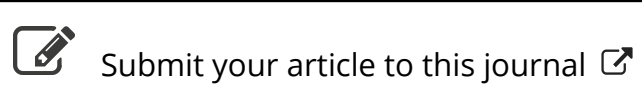

Џll Article views: 81

Q View related articles ¿

View Crossmark data ־

Citing articles: 2 View citing articles ¿ð 


\title{
COMMON CHICORY PERFORMANCE AS INFLUENCED BY IRON CONCENTRATION IN THE NUTRIENT SOLUTION
}

\author{
Arthur Bernardes Cecílio Filho, ${ }^{1}$ Juan Waldir Mendoza Cortez, ${ }^{1}$ \\ Daniel de Sordi, ${ }^{1}$ and Miguel Urrestarazu ${ }^{2}$ \\ ${ }^{1}$ Plant Production Departament, Universidade Estadual Paulista (UNESP), São Paulo, \\ Brazil \\ ${ }^{2}$ Departamento de Agronomía, Universidad de Almería, Almería, Spain
}

\begin{abstract}
$\square \quad$ An experiment was carried out from February 25 till April 10 of 2010 at the Jaboticabal campus of the Paulista State University (UNESP), state of São Paulo, Brazil, viewing to find out which would be the optimum and the phytotoxic levels of iron in the nutrients solution for common chicory (Cichorium intybus) plants. Iron concentrations in the nutrients solution were of 0.9, 2.7, 8.3, and $25 \mathrm{mg} \mathrm{L} \mathrm{L}^{-1}$. These treatments were replicated 4 times and the experimental units were distributed according to a randomized complete block design. The nutrient film hydroponic technique (NFT) was used. Growth parameters such as plant height and number of leaves as well as reproductive parameters such as green and dry mass production were evaluated. The optimal concentrations were found to be between 2.7 and $8.3 \mathrm{mg} \mathrm{L^{-1 }}$ of iron in the nutrients solution. The concentration of $25 \mathrm{mg} \mathrm{L^{-1 }}$ caused toxicity, although no visual sign of iron in excess was observed.
\end{abstract}

Keywords: Cichorium intybus, soilless culture, mineral nutrition of $\mathrm{Fe}$, hydroponic

\section{INTRODUCTION}

Common chicory (Cichorium intybus), which is a leaf vegetable belonging in the Asteraceae family, is recently gaining a lot of importance due to its nutritional properties since it is very rich in mineral salts, mainly calcium, phosphorus, iron, vitamins $\mathrm{A}$ and of the $\mathrm{B}$ complex as well as because of its pharmaceutical properties: the leaves are used as a diuretic and the roots, which may be used in detoxifying treatments of the liver and kidneys (Cavarianni et al., 2005). Common chicory is one of the most important plants from

Received 30 September 2012; accepted 30 October 2014.

Address correspondence to Miguel Urrestarazu, Departamento de Agronomía, Universidad de Almería, La Cañada de San Urbano, E-04120 Almería, Spain. E-mail: mgavilan@ual.es

Color versions of one or more of the figures in the article can be found online at www.tandfonline. com/lpla. 
which oligosaccharides can be extracted. These nonconventional sugars are widely used in the food industry because they show excellent functional characteristics in foods (Spiegel et al., 1994) and in non-food products as well (Fuchs, 1987). The use of those sugars is growing rapidly all over the world.

Nowadays, in Brazil, the most widely used hydroponics technique is that known as the nutrient film technique (NFT), which is used almost exclusively for the production of lettuce. Lettuce is a highly profitable crop in the period between November and March but lowly profitable in the complementary period, thus suggesting that it might be totally or partially replaced by another crop. Chicory may be that crop since its requirements as to management of hydroponic systems are similar to those of lettuce and also because on a yearly average basis, chicory is more profitable than lettuce.

Few are the studies concerning the effects of Fe excesses or deficiencies on the growth and production of species cultivated in hydroponic systems (Misra and Sharma, 1991, 2006; Yeritsan and Economakis, 2002; Assimakopoulou, 2006; Nenova, 2006, 2009).

Iron ( $\mathrm{Fe}$ ) is the micronutrient more intensively absorbed by chicory and its effect is strongly associated with photosynthesis (Grusak et al., 1999). If absorbed in excess, Fe causes the leaves to develop a bronze color or a darker green or even a reddish color followed by an inter nervure chlorosis with brown spots which become necrotic followed by a wrinkling of the leaf surface. Fe deficiency causes damage to cell components and this affects physiological processes as well as water and nutrients transport. The aerial part of the plant has its growth retarded, the photosynthetic activity is reduced and the concentrations of potassium and nitrogen are affected (Albano and Miller, 1998; Li et al., 2001; Asch et al., 2005; Becker and Asch, 2005). The importance of the toxicity and deficiency of Fe under soilless and hydroponic crop have been widely reported (e.g. Urrestarazu et al., 2008).

The objective of this research work was to evaluate which the optimum concentration of $\mathrm{Fe}$ is for common chicory plants growing in nutrients solution and which the concentration for the development of visual toxicity symptoms in the plant leaves.

\section{MATERIAL AND METHODS}

The experiment was conducted from 25 of February to the 11 of April of 2010 under greenhouse conditions in Jaboticabal, state of São Paulo, Brazil, at the South latitude of $21^{\circ} 15^{\circ} 22^{\prime \prime}$ and West longitude of $48^{\circ} 18^{\circ} 58^{\prime \prime}$ and an altitude of $575 \mathrm{~m}$ above mean sea level.

Seeds of the 'Folha larga' chicory cultivar were sown in $2 \times 2 \times 2 \mathrm{~cm}$ phenolic foam (Green Up ${ }^{\circledR}$, Kent, OH, USA) with three seeds per cell at a depth of $0.5 \mathrm{~cm}$. The seedlings were daily irrigated and when showing the first leaf they were transferred to a workbench in a nursery with NFT 
$5 \mathrm{~cm}$ wide and $2 \mathrm{~cm}$ high polypropylene channels and a spacing of $5 \mathrm{~cm}$ between seedlings. The nutrients solution at that moment had the lowest Fe concentration $\left(0.9 \mathrm{mg} \mathrm{L}^{-1}\right)$. When the seedlings reached the 3 leaf stage, they were transplanted to the definitive cultivation channels. The channels were spaced of $15 \mathrm{~cm}$ and the plants of $10 \mathrm{~cm}$. The channels were made of PVC and were $10 \mathrm{~cm}$ wide covered with polystyrene plates in which openings of $3 \mathrm{~cm}$ of diameter were perforated to permit a seedling to grow through each one of them. On the same day the seedlings were transplanted, the Fe concentration of the nutrients solution was changed to those of $0.9,2.7$, 8.3 , and $25 \mathrm{mg} \mathrm{L}^{-1}$. The concentrations of the other nutrients were those recommended by Sonneveld and Straver (1994).

The everyday addition of water to the reservoir helped to maintain its level, and $\mathrm{pH}$ was kept at 5.5-6.2 throughout the whole period by the addition of nitric acid or potassium hydroxide, as required by the situation. The initial electrical conductivity of the nutrients solution was of $2.1 \mathrm{dS} \mathrm{m}^{-1}$ and when it reached $1.6 \mathrm{dS} \mathrm{m}^{-1}$ it was replaced by a new one. The nutrients solution circulation was intermittent and controlled by a timer with a volume of 1.75 $\mathrm{L} \min ^{-1}$. During the period from 6 to 10 a.m. and from 4 to 7 p.m., the nutrients solution was made to circulate for 10 minutes followed by a 20 minute period without circulation. In the period between $10 \mathrm{a} . \mathrm{m}$. and 4 p.m., the nutrients solution was made to circulate for 10 minutes, followed by 10 minutes without circulation. Between 7 p.m. and 6 a.m., only a 10 minutes circulation was made at midnight.

Harvest took place on April 10, that is, 44 days after seed sowing. The following characteristics were evaluated: a) plant height, in $\mathrm{cm}$, which was considered the length between the expanded polystyrene plates up to the apex of the leaf. This height was evaluated since the application of the treatments till harvest, with 4 day intervals; b) number of leaves per plant evaluated simultaneously with plant height; c) fresh weight of the plant aerial part by cutting the plant at the height of the polystyrene plates and weighing it in a scale with a centesimal level of precision; d) dry matter weight of the plant aerial part which resulted from the drying of the fresh plant aerial part in an oven with forced air circulation at $65^{\circ} \mathrm{C}$ till constant weight, and $\mathrm{f}$ ) the visual symptoms of Fe deficiency and/or the Fe toxicity to the plants.

The experimental designs and data analyses were based on the procedure described by Little and Hills (1987) and Petersen (1994). The Statgraphics Plus 4.1 statistical package was used to calculate data (Statistical Graphics Corp., Rockville, MD, USA).

\section{RESULTS AND DISCUSSION}

The highest concentration of $\mathrm{Fe}\left(25 \mathrm{mg} \mathrm{L}^{-1}\right)$ caused toxicity to the plants as indicated by plant height starting 20 days after transplanting 


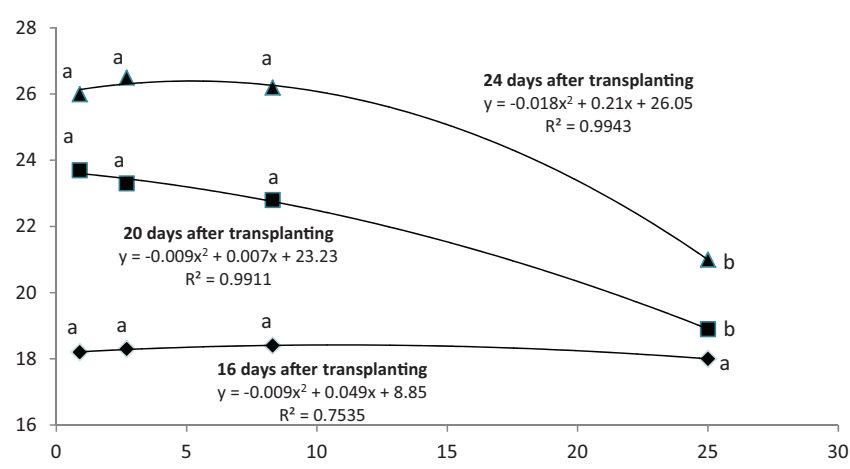

FIGURE 1 Plant height $(\mathrm{cm})$ of chicory in a NFT system according to Fe concentration $\left(\mathrm{mg} \mathrm{L}^{-1}\right)$ in the nutrient solution with 16, 20 and 24 days after transplanting. Different letter indicate significant differences at $95 \%$ according to Tukey's test.

(DAT) (Figure 1) and so maintained up to harvest. Significant quadratic equations were adjusted, showing up to $50 \%$ of reduction in plant height.

The mean number of leaves per plant responded to the increment in $\mathrm{Fe}$ concentration in a way similar to that verified with plant height (Figure 2). These are results similar to those reported by Nenova (2006), who worked with peas. Misra and Sharma (2006) verified that Java citronella plants 95 DAT had grown significantly more when they had been treated with $5.6 \mathrm{mg}$ $\mathrm{L}^{-1}$ of $\mathrm{Fe}$ in the nutrients solution.

Plant aerial part fresh and dry weight also evidenced the toxic effect of the dose of $25 \mathrm{mg} \mathrm{L}{ }^{-1}$ of Fe in the nutrients solution (Figure 3). These characteristics underwent reductions of up to $90 \%$. Common chicory fresh weight was higher when the plants had received the dose of $9.5 \mathrm{mg} \mathrm{L}^{-1}$ of Fe in the nutrients solution - it was $8 \%$ and $68 \%$ higher than that of the doses of

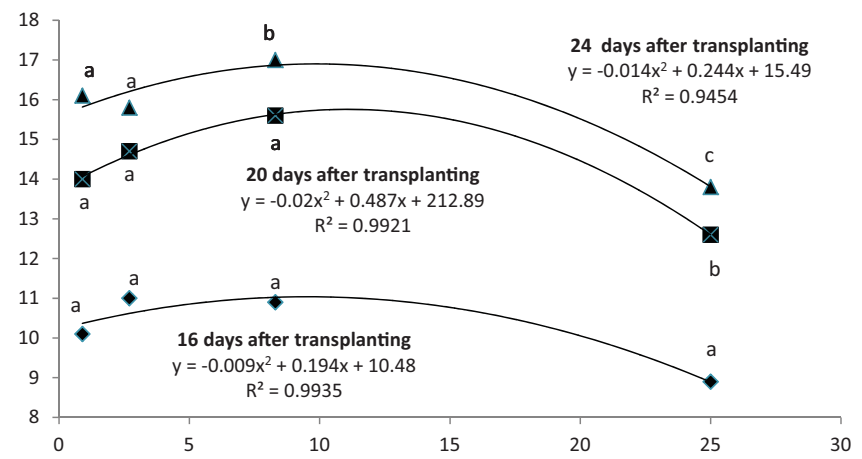

FIGURE 2 Number of leaves of chicory in a NFT system according to Fe concentration $\left(\mathrm{mg} \mathrm{L}^{-1}\right)$ in the nutrient solution with 16, 20 and 24 days after transplanting. Different letter indicate significant differences at $95 \%$ according to Tukey's test. 


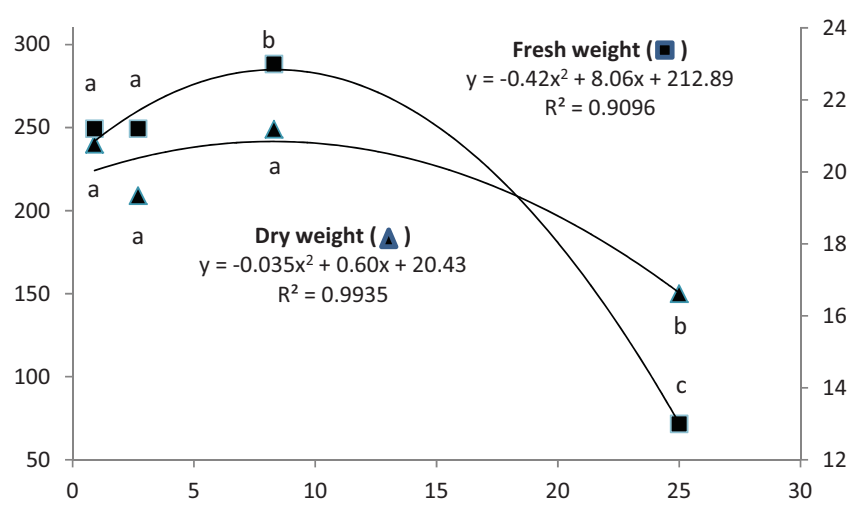

FIGURE 3 Yield (g plant ${ }^{-1}$ ) of leaves of chicory in a NFT system according to Fe concentration $\left(\mathrm{mg} \mathrm{L}^{-1}\right)$ in the nutrient solution. Different letter indicate significant differences at $95 \%$ according to Tukey's test.

$0.9 \mathrm{mg} \mathrm{L}^{-1}$ and $25 \mathrm{mg} \mathrm{L}^{-1}$, respectively. So, the best results did not occur at the theoretical optimum proposed by Sonneveld and Straver (1994) or local researchers such as Furlani (1995), but when Fe concentration was between 2.7 and $8.3 \mathrm{mg} \mathrm{L}^{-1}$.

Misra and Sharma (1991, 2006) and Yeritsyan and Economakis (2002) reported mint (Mentha arvernsis), oregano (Origanum vulgare spp hirtum), and lemongrass (Cymbopogon winterianus) highest yields to occur at the respective doses of $5.6,5.0$, and $2.8 \mathrm{mg} \mathrm{L}^{-1}$ of $\mathrm{Fe}$ in the nutrients solution. They also verified plant growth and yield reductions when Fe was present at the maximum concentration (22.4, 11.0, and $44.8 \mathrm{mg}$ $\mathrm{L}^{-1}$, respectively) in the nutrients solution. It is thus possible to verify that the optimum Fe concentration in the nutrients solution for maximum productivity is quite variable with plant species. Fe concentrations of $20 \mathrm{mg} \mathrm{L}^{-1}$, for instance, which, for some species such as common spinach (Spinacea oleracea) (Assimakopoulou, 2006), is the optimum concentration, for common chicory is very toxic. Thus, the cultivation conditions and the plant species are factors of crucial importance in defining the optimum Fe level to be maintained in the nutrients solution for maximum productivity.

In the research work herein reported, no visual sign of Fe toxicity was observed, this being contrary to what Urrestarazu et al. (2008), Marschner (1995), De Vos et al. (1996), Albano and Miller (1998), Li et al. (2001), Asch et al. (2005), and Becker and Asch (2005) reported; specially in soilless culture like tomato and green bean crop by Urrestarazu et al. (2008). But, even if no toxicity visual signs were found, the highest concentrations of Fe in the nutrients solution determined considerable reductions in chicory plant growth and yield. 


\section{CONCLUSIONS}

Common chicory grown under hydroponics conditions exhibit highest productivity when the Fe concentration in the nutrients solution is between 1.8 and $8.3 \mathrm{mg} \mathrm{L}^{-1}$.

Between the concentrations of 0.9 and $25 \mathrm{mg} \mathrm{L}^{-1}$ of Fe in the nutrients solution no visual signs of Fe deficiency or toxicity were observed, although the concentration of $25 \mathrm{mg} \mathrm{L}^{-1}$ was determinant of severe yield reduction.

\section{REFERENCES}

Albano, J. P., and W. B. Miller. 1998. Marigold cultivars vary in susceptibility to iron toxicity (Tagetes erecta L.). Hortscience 33: 1180-1182.

Asch, F., M. Becker, and D. S. Kpongor. 2005. A quick and efficient screen for resistence to iron toxicity in lowland rice (Oriza sativa L.). Journal of Plant Nutrition and Soil Science 168: 764-773.

Assimakopoulou, A. 2006. Effect of iron supply and nitrogen form on growth, nutritional status and ferric reducing activity of spinach in nutrient solution culture. Scientia Horticulturae 110: 21-29.

Becker, M., and F. Asch. 2005. Iron toxicity in rice (Oriza sativa L.) - conditions and management concepts. Journal of Plant Nutrition and Soil Science 168: 558-573.

Cavarianni, R. L., A. B. Cecílio Filho, R. L. Coelho, and J. O. Cazetta. 2005. Teor de nitrato em cultivares de almeirão, cultivadas em hidroponia, em função do horário de colheita [Nitrate content in chicory cultivars grown in hydroponics, as a function ofharvest time]. Cientifica 33: 50-56.

De Vos, C. R., H. J. Lubberding, and H. F. Bienfait. 1996. Rhizosphere acidification as a response to iron deficiency in bean plants. Plant Phisiology 81: 842-846.

Fuchs, A. 1987. Potentials for non-food utilization of fructose and inulin. Starch/Stärke 10: 335-343.

Furlani, P. R. 1995. Cultivo de Alface Pela Técnica da Hidroponia [Lettuce crop by hydroponics]. Campinas, Brasil: Instituto Agronômico de Campinas.

Grusak, M. A., J. N. Pearson, and E. Marents. 1999. The physiology of micronutrient homeostasis in field crops. Field Crops Research 60: 41-56.

Li, H., X. Yang, and A. Luo. 2001. Amelioration effect of potassium on iron toxicity in hybrid rice. Journal of Plant Nutrition 24: 1849-1860.

Little, T. M., and F. J. Hills. 1987. Métodos Estadísticos para la Investigación en la Agricultura. [Statistical Methods for Research in Agriculture]. Mexico City, Mexico: Ed. Trillas.

Marschner, H. 1995. Mineral Nutrition of Higher Plants. New York: Academic Press.

Misra, A., and S. Sharma. 1991. Critical concentration of iron in relation to essential oil yield and quality parameters of Japanese Mint. Soil Science and Plant Nutrition 37: 185-190.

Misra, A., and S. Sharma. 2006. Critical Fe concentration and productivity of Java citronella. Revista Brasileira de Plantas Medicinais 8: 54-58.

Nenova, V. R. 2006. Effect of iron supply on growth and photosystem II efficiency of pea plants. General and Applied Plant Physiology 37: 81-90.

Nenova, V. R. 2009. Growth and photosynthesis of pea plants under different iron supply. Acta Physiologiae Plantarum 31: 385-391.

Petersen, R. G. 1994. Agricultural Field Experiments. New York: Marcel Dekker Inc.

Sonneveld, C., and N. Straver. 1994. Nutrient Solutions for Vegetables and Flower Grow in Water Substrates. Naaldwijk, the Netherlands: Proefstation voor tuinbouw onder glas te Naaldiwjk.

Spiegel, J. E., R. Rose, P. Rarabell, V. H. Frankos, and D. F. Schmitt. 1994. Safety and benefits of fructooligosaccharides as food ingredients. Food Technology 48: 85-89.

Urrestarazu, M., J. E. Álvaro, S. Moreno, and G. Carrasco. 2008. Remediation of iron chlorosis by the addition of Fe-o, o-EDDHA in the nutrient solution applied to soilless culture. HortScience 43: 1434-1436.

Yeritsyan, N., and C. Economakis. 2002. Effect of nutrient solution's iron concentration on growth and essential oil content of oregano plants grown in solution culture. Acta Horticulturae 576: 277-283. 